\title{
GLL
}

(2) Geomatics, Landmanagement and Landscape No. $2 \cdot 2021,71-86$

\section{VERTICAL DISPLACEMENT MEASUREMENTS AS AN IMPORTANT ASPECT OF EDUCATION OF GEODETIC SURVEYORS}

\author{
Zbigniew Muszyński, Paulina Kujawa
}

\section{Summary}

The rapid development of industry, the automation of production, processing, and mining processes increasingly put more demands on the scope and accuracy of geodetic surveying. Obtaining precise data on the spatial location of objects involved in the production process is indispensable for the efficient management of that process. Registered changes in the geometry of objects may indicate potential threats that may adversely affect the safe operation of the given object. One of the most difficult tasks in engineering surveying is the control of displacements and deformations of building objects and their surroundings. This issue is very broad and concerns most industrial facilities, including opencast mines, landslide areas, cooling towers, water dams, as well as securing deep excavations in compact urban development, verticality control of industrial chimneys and wind farms. Each object has its own specific features and requires an individual approach in the field of measuring network design, the selection of an appropriate measurement technique, and systematic geodetic monitoring of displacements. The key aspect is the professional experience of the surveyor - the geodesist who is managing this type of work. Already at the stage of educating future engineers, it is important not only to provide them with appropriate theoretical knowledge, but also to enable them to acquire practical skills. For this reason, science camps have been organized since 2013 as part of the process of educating geodesy and cartography students at the Wrocław University of Science and Technology. The thematic scope of the camps includes the measurement of displacements of a unique engineering structure over 50 meters high, which is the figure of Christ the King of the Universe, located in Swiebodzin. Students gain professional experience using the latest measuring instruments: digital precision levels, motorized electronic total stations, GNSS satellite receivers, and laser scanners. The students, who face real-life surveying challenges, gain valuable professional experiences that improve their qualifications and better prepare them for their future work. The article presents science camps as one of the additional forms of educating surveyors. The scope of work performed during the science camp is presented, and the basic measurement techniques are described. Particular attention was paid to the empirical assessment of the accuracy of the results of measurements of vertical displacements performed by students using the precision levelling method. For the measurement data collected over a period of 8 years, the mean levelling errors were calculated on the basis of the 
analysis of the levelling sections and polygons. The obtained accuracy meets the requirements for measurements performed in order to determine vertical displacements.

\section{Keywords}

vertical displacements $\bullet$ precise levelling • empirical accuracy assessment $\bullet$ science camps

\section{Introduction}

The technological progress observed in recent years has an impact on the development of many fields of science. The possibilities of contemporary geodesy and metrology shape a new way of understanding the subject matter of monitoring changes in the geometry of industrial objects, and the latest measurement techniques provide increasingly precise data on the spatial location of objects. The task of a geodetic surveyor is to skilfully use the possibilities of modern measurement techniques and to adapt them to the needs of determining displacements and deformations of specific engineering structures, taking into account the individual characteristics of these objects. In such a case, typically, theoretical knowledge alone is insufficient; in addition, professional experience in the implementation of this type of surveying work is very much needed. Therefore, it is important to introduce practical issues related to geodetic monitoring of displacements already at the stage of professional training of the future surveyor. Many technical universities throughout the world update their study programs on an on-going basis, adjusting the educational programs and courses they offer to the current and anticipated requirements of the labour market. Nevertheless, the number of hours of practical measurement classes during the semester is fairly limited, for obvious reasons, and as such it does not ensure the students' familiarity with all the latest measurement techniques. For this reason, internships and science camps constitute a valuable form of supplementing students' competences.

\section{Significance of measuring displacements within industrial facilities}

Definitions related to geodetic determination of displacements can be found in Polish Standards [PN-86-N-02207, PN-N-02211], which describe this process as detecting changes in the position of specific points in the given, considered time, with selected geodetic methods. Industrial facilities, such as: cooling towers, cranes, power plants, industrial chimneys, bridges, tunnels, or hydro-technical facilities [Regulation 2007], require regular monitoring of displacements and deformations, both during the construction of these facilities, and then during their subsequent long-term operation. Displacement measurements also cover mining areas and zones that are adversely affected by mining activities. Changes in the geometrical shape of an engineering structure may be caused by external and/or internal factors, such as, for example, the duration of use of the facilities, the influence of environmental factors (temperature, humidity, wind, or snow loads), the unfavourable influence of mining activities in the vicinity, improper interaction of the building's foundations with the ground on which 
it is founded, or abnormalities at the stage of design, implementation, and operation of the given engineering structure [Muszyński et al. 2011]. A significant influence of any of these factors may lead to a threat to the stability of the structure and, as a result, even to a construction disaster. For this reason, designers of building structures increasingly often decide to cooperate with surveyors in the field of controlling changes in the geometry of objects, implemented in the form of geodetic control measurements or the application of building monitoring systems [Gierski et al. 2016]. Pursuant to Polish law, the information on the need to perform geodetic measurements of displacements and deformations is attached to the construction design as a descriptive part of the technical design [Regulation 2020a]. The entire construction investment process is regulated by the Act [Act 1994], in which article 27a relates to surveying activities. Until recently, the scope of surveying activities was further specified in the Regulation [Regulation 1995], which was repealed in July 2020. Currently, the definition of surveying activities for the construction industry can be found in Article 2 of the amended Act [Act 1989]. Detailed standards for the performance of surveying measurements, including for the purposes of implementation measurements, had been previously included in the regulation [Regulation 2011], which was repealed in August 2020 and replaced by the current regulation [Regulation 2020b].

Geodetic control measurements are defined as the process of obtaining information about engineering objects by measuring the geometry of the building at a given moment of time, followed by processing the obtained data and their appropriate analysis [Duda and Kryzia 2010]. In the case of geodetic monitoring, it also allows for the assessment of the condition of the examined object, while the monitoring may take the form of periodic measurements performed cyclically, or it may be carried out in a continuous manner. The main purpose of geodetic measurements of displacements and deformations within industrial facilities is to avoid possible threats related to the operation of the facility, and to ensure the safety of people staying inside or near the tested facility. The data obtained as a result of geodetic measurements are necessary to assess whether the object behaves in accordance with the design assumptions, and to allow for a sufficiently quick response in the event of excessive displacements [Gierski et al. 2016]. It is also essential to avoid material losses for investors and users of the facilities where displacements have been detected. Therefore, the awareness of the importance of displacement and deformation measurements must be passed on to young people who study at technical universities as future surveyors.

\section{Geodetic measurements of displacements in the education of surveyors}

\subsection{Learning process in higher education institutions}

According to the assumptions of the Bologna process, higher education in Europe is divided into threelevels of education: 1) first-cycle studies leading to the award of a professional engineer or bachelor's degree, 2) second-cycle studies leading to the professional title of "magister" or master of engineering, 3) third-cycle studies ending with the award of a doctoral degree. As part of the first two levels of education, universities offer curri- 
cula for individual fields of study, and sometimes also specialties. The implementation of the university's mission, the adjustment of the educational offer to the changing requirements of the labour market, and equipping graduates with the necessary knowledge and skills adequate to technological progress all require systematic updating of the content and forms of instruction. Discussions on this topic are conducted for many fields of science and many study fields, such as: geodesy [Enemark 2005, Potůčková 2006, Young et al. 2012, Bolkas and Gouak 2020], geotechnical engineering [Jaksa et al. 2012, Jaksa 2012, Orr and Pantazidou 2012], mining [Malcolm and Laurence 2008, Kazanin and Drebenstedt 2017, Puchkov and Petrov 2017], or architecture [Mayer and Mitterecker 2017]. In addition to the topicality of the knowledge provided, a lot of emphasis is placed on practical vocational training and gaining the broadest possible professional experience. For this purpose, elements supplementing the typical education process are often introduced, such as student apprenticeships, research projects carried out within science clubs, or science camps for a selected group of the best students. These activities may take the form of collaborative activities between employers, universities, or other organizations. Sometimes this collaboration has an international scope, an example of which can be found, among others, in Sitanyiova et al. [2014], Rybak et al. [2017].

\subsection{Educating geodesy and cartography students at the Wrocław University of Science and Technology}

First-cycle studies in the field of geodesy and cartography have been offered at the Faculty of Geoengineering, Mining and Geology of the Wrocław University of Science and Technology since October 2011. Engineering studies last 7 semesters and, in addition to the obligatory courses during the academic year, they include fieldwork classes conducted during the summer holidays after the second, fourth and sixth semester of studies. In addition, students complete the obligatory apprenticeship in a geodetic company and geodetic administration, the total duration of which is at least 3 weeks. Furthermore, science camps are organized on a non-obligatory basis, for those who wish to participate; and another opportunity is to join one of several student science clubs. Since February 2018, it is possible to continue education at second-cycle (master's level) studies in geomatics.

\subsection{Science camp in Świebodzin as an additional form of education}

The science camp in Świebodzin, organized annually since 2013 by Zbigniew Muszyński, is very popular among students of geodesy and cartography. The science camp is combined with compulsory fieldwork classes, which are included in the study program after the fourth semester of engineering studies. As part of fieldwork, among other things, students develop a map for design purposes of a given fragment of the area, a geodetic elaboration of a construction design, establishing the control survey network, determining the intersections of the building's structural axes, and transferring assembly indicators to higher floors. The subject matter of the science 
camp focuses on measuring the displacements of the statue of Christ the King of the Universe, which is located in Świebodzin (Poland). Students perform precision levelling measurements in order to determine vertical displacements, and total station and satellite measurements using the GNSS static technique to determine horizontal displacements. In selected periods, terrestrial laser scanning is also performed inside and outside the statue. Participation in the science camp allows students to face the full range of difficulties and challenges faced by a surveyor when measuring displacement of building object. Precise levelling of sections, terrain with a relative heights

a)

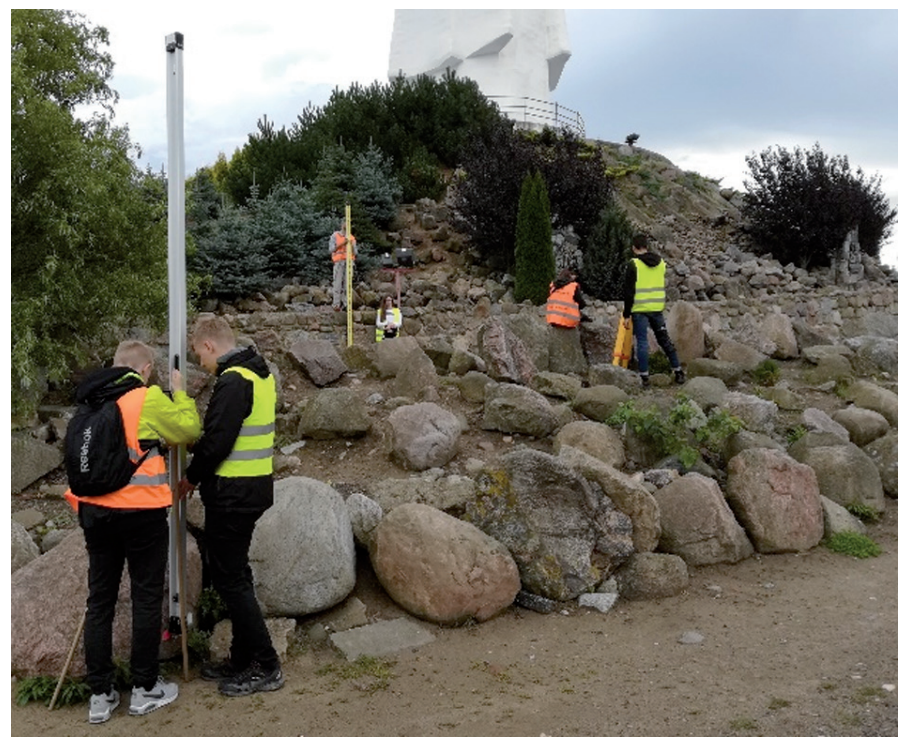

b)

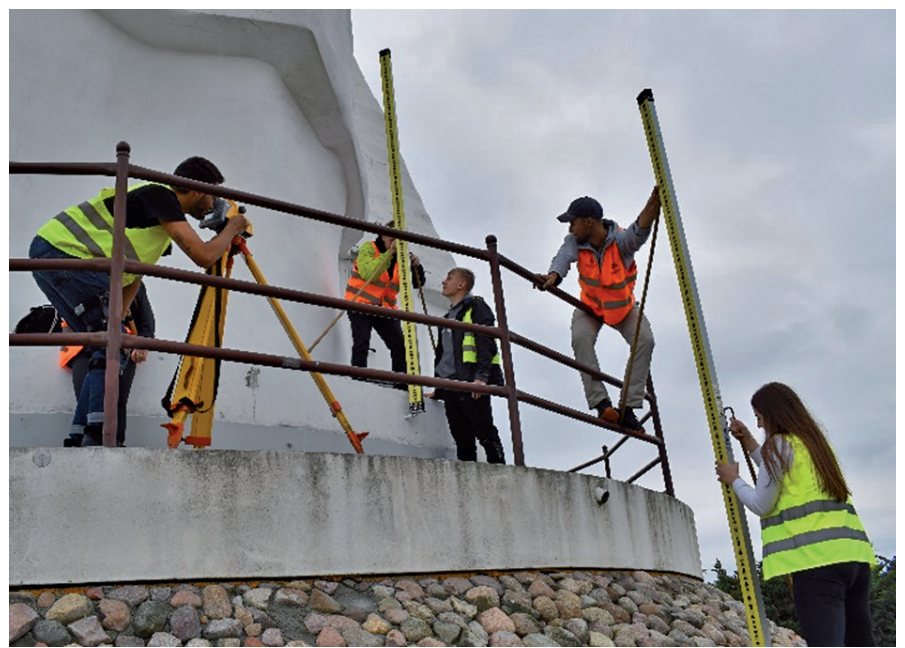

Fig. 1. Measuring vertical displacements: a) view of the mound, b) approach to the base (pedestal) of the statue 
difference of a dozen or so meters (Fig. 1), steep climb up the stairs, the influence of atmospheric refraction, and sometimes wind and air vibrations from the heated asphalt surface teach the students how to deal with measurements, and allow them to gain valuable professional experience. In addition, students expand their knowledge by participating in a lecture and educational excursions specially organized for them.

\section{Characteristics of selected geodetic measurement techniques used during student science camps}

\subsection{Establishing vertical displacements - precision levelling}

Vertical displacement measurements are one of the basic geodetic measurement methods used to detect geometric and structural changes of buildings, structures and/or their parts in the specific considered time [Bryś and Przewłocki 1998]. Contemporary coded precision levelling instruments with the use of invar levelling rods make it possible to achieve the accuracy of measuring height differences at the level of $0.3 \mathrm{~mm}$ per $1 \mathrm{~km}$ of double geometric levelling. The process of determining vertical displacements begins with the establishment of a levelling network consisting of reference points and controlled points [Muszyński 2015]. The reference points should be outside the range of the impact of the monitored object on the surroundings, and their task is to materialize the height frame of reference. The controlled points are stabilized on the tested object, and any changes to their position testify to the displacements of that tested object [Prószyński and Kwaśniak 2006]. The initial (starting) measurement should be performed after the completion of the construction of the object, and subsequent measurements (named as control measurements) should be carried out periodically, at regular intervals, appropriately selected for the specificity of the monitored object or facility.

In order to obtain high-quality observational data, it is necessary to follow appropriate measurement procedures, e.g. double measurement of the height difference at each levelling station, proper order of readings from the levelling rods (backward, forward, forward, backward), even number of levelling stations, double measurement of each levelling section, replacement of the levelling rod on the initial benchmark between the measurement of the section in the main direction and backward. It is very important to control the obtained measurement deviations on an ongoing basis, as well as perform the final verification of the obtained observation material, which enables the empirical assessment of the accuracy of the measurement results. This assessment can be made on the basis of the two quantities described below: $\rho$ and $f$.

a) Two adjacent, permanently stabilized benchmarks, which are connected by a line of geometric levelling, form a levelling section. According to the rules of surveying, each levelling section is measured twice: in the main direction and backward. By comparing the differences in height from the double measurement of each section, it is possible to calculate the deviations, and then determine the mean error of levelling, calculated per $1 \mathrm{~km}$ (1) or per one levelling station (2) [Osada 2002]: 


$$
\begin{aligned}
& m_{1(\mathrm{~km})}= \pm \frac{1}{2} \sqrt{\frac{1}{n_{R}} \cdot \sum_{i=1}^{n_{R}} \frac{\rho_{i}^{2}}{R_{i}}} \\
& m_{1(\mathrm{st})}= \pm \frac{1}{2} \sqrt{\frac{1}{n_{R}} \cdot \sum_{i=1}^{n_{R}} \frac{\rho_{i}^{2}}{n_{i}}}
\end{aligned}
$$

where:

$m_{1(\mathrm{~km})} \quad$ - the mean error of levelling per $1 \mathrm{~km}$ levelling section,

$m_{1(s t)} \quad$ - the mean error of levelling per one levelling station,

$n_{R} \quad$ - number of levelling sections in the network,

$R \quad$ - length of the $i$-th levelling section $[\mathrm{km}]$,

$n_{i} \quad-$ number of levelling stations in the $i$-th levelling section.

In the case when the levelling sections form closed figures (the so-called levelling polygons), it is possible to calculate the sum of the measured height differences inside the polygon, i.e. the levelling range closure deviation $f$. Upon the examination of all of the $f$ deviations within the whole levelling network, we can calculate the mean levelling error $m_{3}$ given either per $1 \mathrm{~km}$ (3) or per one levelling station (4) [Osada 2002]:

$$
\begin{aligned}
& m_{3(\mathrm{~km})}= \pm \sqrt{\frac{1}{n_{F}} \cdot \sum_{i=1}^{n_{F}} \frac{f_{i}^{2}}{F_{i}}} \\
& m_{3(s t)}= \pm \sqrt{\frac{1}{n_{F}} \cdot \sum_{i=1}^{n_{F}} \frac{f_{i}^{2}}{n_{i}}}
\end{aligned}
$$

where:

$m_{3(\mathrm{~km})}$ - the mean error of levelling per $1 \mathrm{~km}$ levelling section,

$m_{3(s t)}$ - the mean error of levelling per one levelling station,

$n_{F} \quad$ - number of levelling polygons in the developed network,

$F \quad$ - length of the $i$-th levelling polygon,

$n_{i} \quad$ - number of the levelling stations in the $i$-th levelling polygon.

The results of the empirical assessment of accuracy provide the basis for weighting observations when making adjustment of the results using the least squares method. The next step in the processing of measurement data is the identification of the fixed reference benchmarks. For this purpose, various methods or identification strategies can be applied [Ćwiąkała et al. 2015a]. The most popular approach is to control changes in the height difference between pairs of reference benchmarks. All possible combinations of pairs of reference benchmarks are analysed, and the changes are considered in a specific time interval. Raw measurement results or pre-adjusted height differences can be adopted for analysis. The observed changes are compared with the permissible 
values, and thus a subset of the fixed reference benchmarks is defined. The latter serve as reference points for the alignment of the periodic measurement and thus for the calculation of the current height of the controlled benchmarks. On the basis of changes in the height of the controlled benchmarks over time, it is possible to calculate the values of vertical displacements and their average errors.

\subsection{Determination of horizontal displacements - GNSS static measurements and motorized total station measurements}

Determination of horizontal displacements is the second important goal of geodetic monitoring of buildings and their surroundings. Depending on the extent of geodetic network, various measuring techniques are used. In smaller networks, motorized electronic total stations ensuring high accuracy and repeatability of measurements are typically used. Total stations are usually located on the reference points. The measurement consists in the registration of angles and distances to other reference points, and to the points controlled on the facility. Sometimes the total stations are additionally located in temporary stations if there are difficulties in providing adequate visibility of the controlled points [Muszyński 2014, Muszyński and Rybak 2017]. Development of measurement results starts with the identification of fixed reference points. Next, the displacements of the controlled points are determined as changing the position of points in a specific interval for the adopted reference system.

For more extensive measuring networks or in the case of problems with the stability of reference points, satellite measurements (GNSS) in static mode are performed. This is the most accurate method of satellite measurements. Static measurements are also used to establish and control geodetic control networks [Ćwiąkała et al. 2015B]. During the measurement, at least three receivers are required, which remain at the geodetic control network point and synchronously register the observations to the satellites. Measuring sessions can last from an hour to several days. When measuring horizontal displacements, GNSS receivers are usually placed on a reference point, but they can also be placed on controlled points. After post-processing, the observation data provides spatial vectors that are subject to common adjustment with total station observations.

\subsection{Terrestrial laser scanning}

Terrestrial laser scan belongs to the fastest developing measuring techniques for obtaining spatial information.

The principle of the laser scanner operation is based on a remote measurement of points using a laser beam. The instrument, placed in a stationary station, sends a laser impulse that is reflected from the surface of the object and returns to the scanner. Based on the measured distance and angles (both vertical and horizontal), the spatial position of points is determined by calculating $\mathrm{X}, \mathrm{Y}, \mathrm{Z}$ coordinates in the local scanner coordinate system. The rate of measurement, reaching one million points per second, 
makes it possible to obtain a geometric representation of the measured objects in the form of a dense cloud of points. Point clouds obtained from individual scanner positions should be further processed, by registration and filtration. Registration consists in combining scans from individual stations and assigning the target reference system to the point cloud. Filtration is a process of cleaning the point cloud from contamination (i.e., from so-called false reflections) and scanned unnecessary elements (such as cars, vegetation, or people). The processed point cloud can then be subjected to modelling. Terrestrial laser scanning is widely used in many areas of science, including cultural heritage management, for the modelling of monuments and statues [Kuzyk and Berdar 2017]. This technique is also increasingly used in displacement measurements, the examples of which can be found, among others in the works of van Gosliga et al. [2006], Muszyński [2014], Muszyński and Fisherman [2017], Farahani et al. [2019].

\section{Empirical assessment of the accuracy of the results of vertical displacement measurements}

\subsection{The research object}

The studied object is the statue of Christ the King of the Universe located in Świebodzin (Fig. 2). The statue is 36 meters high, and it is set on a specially formed mound, the height of which reaches 14 meters. This is an original engineering structure that was constructed using mixed techniques. The lower fragments of the figure's coat were made of concrete imposed on a skeleton of rods and steel grids, separated by a hard mineral wool. The upper segments of the figure's coat were made of polyurethane foam covered on the outside with resin laminate, reinforced with glass fibre sheets. In addition, in the interior of the figure there is a dense steel structure forming a truss that is connected to the coat. The figure is placed on a foundation plate, embedded in the ground, from which six reinforced concrete columns are raising, placed within the mound. The reinforced concrete columns are topped with an upper concrete slab, and they penetrate further inside the figure [Marcinowski 2011]. The Świebodzin statue is several meters higher than the famous statue of Christ the Redeemer in Rio de Janeiro.

\subsection{Measurement range and characteristics}

Stabilization of benchmarks to measure vertical displacements of the statue of Christ the King was made in 2013. Originally, the network consisted of 9 reference benchmarks and 7 controlled benchmarks, which were located on the circumference of the statue's pedestal (Fig. 3). Measurements of displacements were performed in the intervals of one year. With time, the shape of the geodetic network changed, because additional reference benchmarks were added. The number of levelling sections increased from 24 in the initial measurement, to 37 sections at present. Each section of precision levelling is measured twice (in the main direction and backward), which produces a total of about $12 \mathrm{~km}$ of precision levelling. The measurement results are strictly controlled in real time. Levelling sections that do not meet precision requirements are re-measured. 


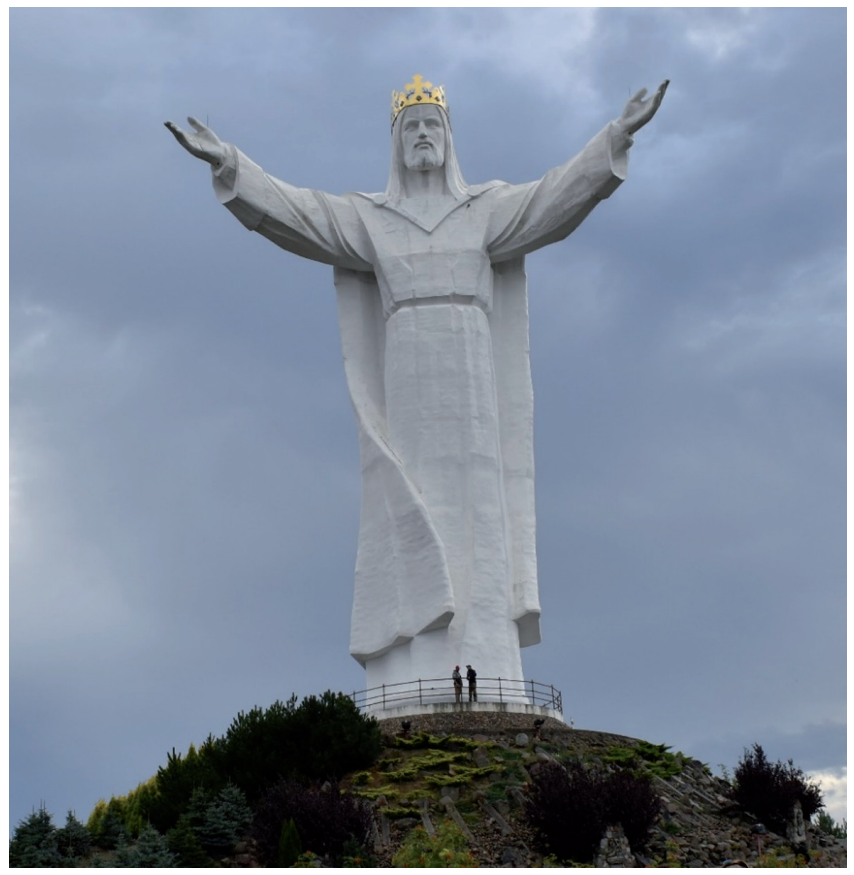

Fig. 2. Statue of Christ the King of the Universe in Swiebodzin

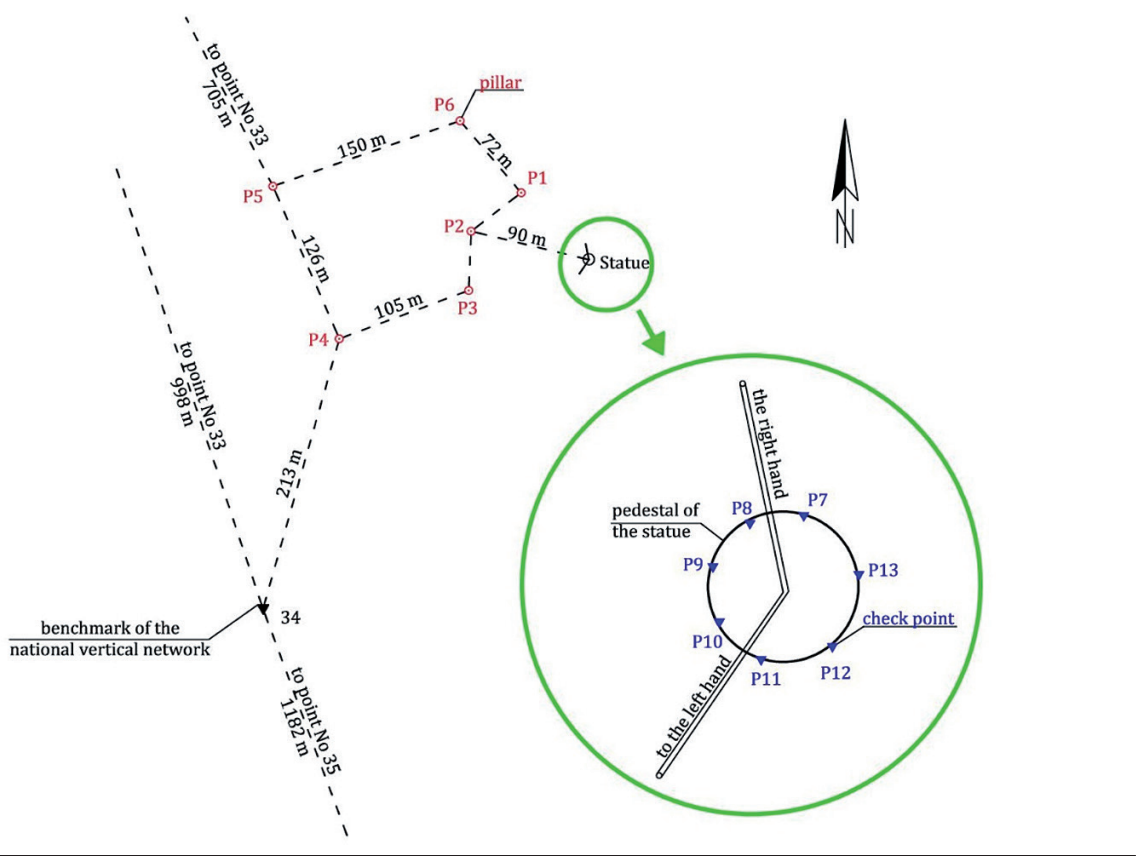

Fig. 3. Placement of the benchmarks during initial measurements in 2013 


\subsection{Results of the empirical accuracy assessment of levelling measurements}

The correct estimation of the accuracy of the levelling measurements is necessary in order to determine the weights in the process of adjustment by the last squares method. The nominal accuracy of the applied measurement instruments is determined by their producers in laboratory conditions. In this case, these were two Trimble DiNi 0.3 code levels, equipped with a set of levelling rods with a nominal accuracy of $0.3 \mathrm{~mm}$ per $1 \mathrm{~km}$ of levelling. Empirical accuracy of the levelling measurements can be estimated on the basis of the deviation between the measurement (repeated twice) of each section (formulas (1) and (2)) or on the basis of the misclosure of the levelling polygons (formulas (3) and (4)). The results obtained from the empirical accuracy assessment for eight precision levelling campaigns are summarized in Tables 1 and 2.

Table 1. Empirical accuracy assessment of measurements, based on the analysis of levelling sections in the network for the examination of vertical displacements

\begin{tabular}{|c|c|c|c|c|c|c|c|c|}
\hline $\begin{array}{c}\text { Year in which the measurement } \\
\text { was performed }\end{array}$ & 2013 & 2014 & 2015 & 2016 & 2017 & 2018 & 2019 & 2020 \\
\hline Number of measurement campaign & 0 & 1 & 2 & 3 & 4 & 5 & 6 & 7 \\
\hline $\begin{array}{l}\text { The number of sections adopted for } \\
\text { the calculations }\end{array}$ & 24 & 26 & 27 & 28 & 38 & 37 & 37 & 37 \\
\hline $\begin{array}{l}\text { Total length of the sections in the } \\
\text { network }[\mathrm{km}]\end{array}$ & 5.174 & 5.984 & 5.105 & 6.537 & 6.433 & 6.019 & 6.144 & 6.097 \\
\hline $\begin{array}{l}\text { Minimum value of the deviation } \rho \\
{[\mathrm{mm}]}\end{array}$ & -0.20 & -0.39 & -0.17 & -0.20 & -0.19 & -0.13 & -0.18 & -0.31 \\
\hline $\begin{array}{l}\text { Maximum value of the deviation } \rho \\
{[\mathrm{mm}]}\end{array}$ & 0.70 & 0.97 & 0.64 & 1.05 & 0.65 & 0.60 & 0.32 & 0.43 \\
\hline Mean value of the deviation $\rho[\mathrm{mm}]$ & 0.07 & 0.06 & 0.02 & 0.02 & 0.07 & 0.04 & 0.04 & 0.03 \\
\hline $\begin{array}{l}\text { Minimum length of the section } \\
{[\mathrm{km}]}\end{array}$ & 0.004 & 0.004 & 0.004 & 0.004 & 0.004 & 0.004 & 0.004 & 0.004 \\
\hline $\begin{array}{l}\text { Maximum length of the section } \\
{[\mathrm{km}]}\end{array}$ & 1.210 & 1.200 & 1.200 & 1.200 & 1.199 & 1.199 & 1.187 & 1.188 \\
\hline $\begin{array}{l}\text { Mean error of the measurement } \\
\mathrm{m}_{1(\mathrm{~km})}[\mathrm{mm} \text { per } 1 \mathrm{~km}]\end{array}$ & 0.176 & 0.259 & 0.334 & 0.176 & 0.231 & 0.246 & 0.237 & 0.250 \\
\hline $\begin{array}{l}\text { Total number of stations adopted } \\
\text { for the calculations }\end{array}$ & 137 & 157 & 163 & 193 & 206 & 191 & 209 & 207 \\
\hline $\begin{array}{l}\text { Minimum number of stations in } \\
\text { the section }\end{array}$ & 1 & 1 & 1 & 1 & 1 & 1 & 1 & 1 \\
\hline $\begin{array}{l}\text { Maximum number of stations in } \\
\text { the section }\end{array}$ & 22 & 22 & 22 & 22 & 22 & 22 & 28 & 28 \\
\hline $\begin{array}{l}\text { Mean error of the measurement } \\
\mathbf{m}_{1(s t)}[\mathrm{mm} \text { per } 1 \text { station }]\end{array}$ & 0.028 & 0.041 & 0.031 & 0.029 & 0.031 & 0.027 & 0.029 & 0.032 \\
\hline
\end{tabular}


Table 2. Empirical accuracy assessment of measurements, based on the analysis of levelling polygons in the network for the examination of vertical displacements

\begin{tabular}{|l|c|c|c|c|c|c|c|c|}
\hline $\begin{array}{l}\text { Year in which the measurement } \\
\text { was performed }\end{array}$ & 2013 & 2014 & 2015 & 2016 & 2017 & 2018 & 2019 & 2020 \\
\hline $\begin{array}{l}\text { Number of measurement } \\
\text { campaign }\end{array}$ & 0 & 1 & 2 & 3 & 4 & 5 & 6 & 7 \\
\hline $\begin{array}{l}\text { The number of polygons adopted } \\
\text { for the calculations }\end{array}$ & 12 & 18 & 22 & 22 & 23 & 22 & 23 & 23 \\
\hline $\begin{array}{l}\text { Total length of the polygons in } \\
\text { the network [km] }\end{array}$ & 6.931 & 8.650 & 10.358 & 10.819 & 11.565 & 11.253 & 11.785 & 11.722 \\
\hline $\begin{array}{l}\text { Minimum value of the } \\
\text { misclosure } f \text { [mm] }\end{array}$ & -0.44 & -0.30 & -0.31 & -0.37 & -0.46 & -0.34 & -0.65 & -0.28 \\
\hline $\begin{array}{l}\text { Maximum value of the } \\
\text { misclosure } f \text { [mm] }\end{array}$ & 0.78 & 0.62 & 0.19 & 0.28 & 0.44 & 0.27 & 0.16 & 0.36 \\
\hline $\begin{array}{l}\text { Mean value of the misclosure } f \\
\text { [mm] }\end{array}$ & 0.02 & 0.09 & -0.09 & -0.06 & -0.07 & -0.07 & -0.18 & 0.11 \\
\hline $\begin{array}{l}\text { Minimum length of the polygon } \\
\text { [km] }\end{array}$ & 0.032 & 0.031 & 0.032 & 0.031 & 0.032 & 0.034 & 0.034 & 0.033 \\
\hline $\begin{array}{l}\text { Maximum length of the polygon } \\
\text { [km] }\end{array}$ & 1.530 & 1.388 & 1.233 & 1.261 & 1.355 & 1.360 & 1.357 & 1.357 \\
\hline $\begin{array}{l}\text { Mean error of the measurement } \\
\text { m }\end{array}$ & 0.385 & 0.418 & 0.260 & 0.293 & 0.395 & 0.221 & 0.431 & 0.416 \\
\hline $\begin{array}{l}\text { Total number of stations in the } \\
\text { polygons }\end{array}$ & 251 & 327 & 456 & 489 & 479 & 454 & 485 & 479 \\
\hline $\begin{array}{l}\text { Minimum number of stations in } \\
\text { the polygon }\end{array}$ & 7 & 7 & 7 & 7 & 6 & 6 & 7 & 7 \\
\hline $\begin{array}{l}\text { Maximum number of stations in } \\
\text { the polygon }\end{array}$ & 34 & 31 & 34 & 35 & 31 & 31 & 32 & 32 \\
\hline $\begin{array}{l}\text { Mean error of the measurement } \\
\mathbf{m}_{3(\text { sst }} \text { [mm per 1 station] }\end{array}$ & $\mathbf{0 . 0 6 3}$ & $\mathbf{0 . 0 7 1}$ & $\mathbf{0 . 0 4 1}$ & $\mathbf{0 . 0 4 2}$ & $\mathbf{0 . 0 5 6}$ & $\mathbf{0 . 0 3 5}$ & $\mathbf{0 . 0 5 7}$ & $\mathbf{0 . 0 4 8}$ \\
\hline
\end{tabular}

\subsection{Discussion}

Analyzing the above results can be seen an increase in the number of measured levelling sections in subsequent measurement campaigns. This resulted from strengthening the construction of the measuring network and the need to stabilize additional reference benchmarks, because some previous benchmarks lost stability of the position. The introduction of additional sections also increased the number of levelling polygons. The longest levelling section on the network connects reference benchmarks numbers 34 and 35. This levelling section originally consisted of 22 locations, and typically it was the one where the largest value of deviation $\rho$ was recorded. Due to frequent difficulties with refracting and air waving from heated asphalt, which resulted in a frequent 
repetition of measurements, since 2019 the number of stations on this levelling section was increased to 28 , while the sights in the stations were reduced to about 20 meters. The shortest levelling sections in the network have sights below 2 meters, and they connect controlled benchmarks on the perimeter of the statue's pedestal (Fig. 3). Due to the lack of space, and the railing around the pedestal (Fig. 1b), these are currently the only levelling sections on the network, where there is an odd number of stations.

The weighting of observations during adjustment process can be performed on the basis of the length of the levelling sections or on the basis of the number of instrument's stations in individual sections. The first method is recommended for a network with a typical length of sights, reaching a maximum of 30 meters. In the analysed network, such levelling sections have occurred along the line of benchmarks 33, 34, and 35. A steep approach with paths and stairs under the statue's pedestal forces significant shortening of the sights. In this case, a better solution is to weigh the observations based on the number of levelling stations. For more complete information, in Tables 1 and 2, the results for both weighting methods have been presented. The empirical value of the mean error $m_{1(\mathrm{~km})}$ remained in the range of $0.176-0.334 \mathrm{~mm}$ per $1 \mathrm{~km}$, which corresponds to the nominal accuracy of the instrument. The empirical value of the mean error $m_{3(\mathrm{~km})}$ was slightly higher, and it remained in the range of $0.221-0.431 \mathrm{~mm}$ per $1 \mathrm{~km}$. When weighting with the use of the number of stations, the following level of accuracy was obtained: $m_{1(s t)}$ in the range $0.027-0.041 \mathrm{~mm}$ per 1 station, and $m_{3(s t)}$ in the range of $0.035-0.071 \mathrm{~mm}$ per 1 station. The obtained results should be regarded as satisfactory, especially considering the fact that measurements were performed by students who are in the process of learning precise levelling.

\section{Conclusions}

Measurements of vertical displacements by precision levelling method are a frequent task in the practice of surveyor-engineer. Increasingly dense built environments in major city centres, combined with the construction of multi-level underground parking in deep excavations forces monitoring of displacements of objects in the vicinity of construction sites. Regular measurements of vertical displacements also apply to industrial facilities, such as, for instance, cooling towers, industrial chimneys, water dams, or power plants. Measurements of displacements should also be applied to unusual objects, which are unique in their structure. The statue of Christ the King of the Universe in Świebodzin has been subjected to measurements of vertical displacements since 2013. These measurements are carried out by students of the Wrocław University of Science and Technology as part of their annual science camps. Despite their lack of previous experience in the processing of such measurements, the quality of collected data does not raise any objections. This is due to the high-quality measuring equipment at the students' disposal, rigorous measurement and control procedures imposed by the camp supervisor, and the high involvement of the students. Taking into account eight previous measurement campaigns, the average empirical accuracy of levelling was $0.239 \mathrm{~mm}$ per $1 \mathrm{~km}$ and $0.031 \mathrm{~mm}$ per 1 station based on the analysis of 
measured levelling sections, and $0.352 \mathrm{~mm}$ per $1 \mathrm{~km}$ and $0.052 \mathrm{~mm}$ per 1 station based on the analysis of levelling polygons. The average value of the vertical displacements of the P7-P13 controlled benchmarks (Fig. 3) in the period 2013-2020 was $-4.3 \mathrm{~mm}$. Participation in the science camp is a chance for students to deepen their professional knowledge and gain valuable experience. Working with modern measuring equipment on a unique object, with all the difficulties occurring during the normal operation of the surveyors, changes the way of that students perceive the profession they are studying for. Their awareness of the importance of geodetic monitoring of displacements, as well as their knowledge of modern measuring techniques both increase. Some of the former participants in the science camp are currently working as research and teaching assistants or doctoral students at the Wrocław University of Science and Technology, and in Germany. Others work in companies involved in the implementation of innovative solutions that combine modern measurement techniques with machine learning. Thus, the science camps are a valuable complement to the compulsory program of study, and, in the long run, can contribute to the development of the university's teaching staff as well as raise the market potential of the graduates undertaking professional work.

\section{References}

Bolkas D., Gouak D. 2020. Understanding the Demographics of Surveying Students in Pennsylvania and Making Plans to Increase the Awareness of the Surveying Profession. Journal of Surveying Engineering, 146(2), 1-19.

Bryś H., Przewłocki S. 1998. Geodezyjne metody pomiarów przemieszczeń budowli. PWN, Warszawa, Poland.

Ćwiąkała P., Deska K., Kocierz R., Ortyl Ł., Owerko T., Puniach E., Skrzypczak I., Tomasz Ś. 2015a. Wybrane problemy geodezji inżynieryjnej. T. Świętoń (ed.), Rzeszów.

Ćwiąkała P., Gabryszuk J., Krawczyk K., Krzyżek R., Leń P., Oleniacz G., Puniach E., Siejka Z., Wójcik-Leń J. 2015b. Technologia GNSS i jej zastosowanie w pomiarach realizacyjnych i kontrolnych. Wyższa Szkoła Inżynieryjno-Ekonomiczna, Rzeszów, Poland.

Duda Z., Kryzia K. 2010. Wykorzystanie monitoringu geodezyjnego do oceny stanu technicznego zabytkowej konstrukcji budowlano-architektonicznej. Górnictwo i Geoinżynieria, 34, $2,211-222$.

Enemark S. 2005. Global Trends in Surveying Education and the role of the SEE: FIG. Azimuth, 43(3).

Farahani B.V., Barros F., Sousa P.J., Cacciari P.P., Tavares P.J., Futai M.M., Moreira P. 2019. A coupled 3D laser scanning and digital image correlation system for geometry acquisition and deformation monitoring of a railway tunnel. Tunnelling and Underground Space Technology, 91, 102995.

Gierski W., Filipiak-Kowszyk D., Makowska K., Kamiński W. 2016. Wykorzystanie lokalnych współczynników wariancji w ocenie istotności przemieszczeń obiektów inżynierskich. I-NET.PL Sp. J., Gdańsk.

Gosliga van R., Lindenbergh R., Pfeifer N. 2006. Deformation analysis of a bored tunnel by means of terrestrial laser scanning. Proceedings of the ISPRS Commission V Symposium on Image Engineering and Vision Metrology, 167-172.

Jaksa M. 2012. Interactive learning modules in geotechnical engineering. Shaking the Foundations of Geo-engineering Education, 131-135. 
Jaksa M., Airey D., Kodikara J., Shahin M., Yuen S. 2012. Reinventing geotechnical engineering laboratory classes. Shaking the Foundations of Geo-engineering Education, 137-142.

Kazanin O.I., Drebenstedt C. 2017. Mining education in the 21st century: Global challenges and prospects. Journal of Mining Institute.

Kuzyk Z., Berdar F. 2017. Methodological and Technological Aspects of 3D Modelling of Historic Memorials and Statues in Order to Document and Preserve Objects of Cultural Heritage. Geomatics, Landmanagement and Landscape, 4(4), 67-77.

Malcolm S., Laurence D. 2008. Future mining engineers: Educational development strategy. Proceedings of the First International Future Mining Conference and Exhibition, 237-242.

Marcinowski J. 2011. Krótka historia wielkiego przedsięwzięcia. Zielona Góra-Świebodzin. Zakład Poligraficzny Uniwersytetu Zielonogórskiego.

Mayer I., Mitterecker T. 2017. Surveying for architectural students: As simple as possible - As much as necessary. ISPRS Annals of the Photogrammetry, Remote Sensing and Spatial Information Sciences, 4(2W2), 135-141.

Muszyński Z. 2014. Assessment of suitability of terrestrial laser scanning for determining horizontal displacements of cofferdam during modernization works on the redzin sluice. Proceedings of the International Multidisciplinary Scientific GeoConference Surveying Geology and Mining Ecology Management, SGEM. 14th International Multidisciplinary Scientific Geoconference and EXPO, SGEM 2014. International Multidisciplinary Scient, 2, 81-88.

Muszyński Z. 2015. Displacement measurements of the statue of Christ the king in Swiebodzin - first results. International Multidisciplinary Scientific GeoConference Surveying Geology and Mining Ecology Management, SGEM.

Muszyński Z., Rybak J. 2017. Evaluation of Terrestrial Laser Scanner Accuracy in the Control of Hydrotechnical Structures. Studia Geotechnica et Mechanica, 39(4), 45-57.

Muszyński Z., Rybak J., Szot A. 2011. Monitoring of structures adjacent to deep excavations. Underground Infrastructure of Urban Areas, 2, 168-174.

Orr T., Pantazidou M. 2012. Use of case studies in geotechnical courses. Shaking the Foundations of Geo-engineering Education, 105-110.

Osada E. 2002. Geodezja. Podręcznik elektroniczny w Mathcadzie 2001i. Oficyna Wydawnicza Politechniki Wrocławskiej, Wrocław, Poland.

Polska Norma PN-86-N-02207 Geodezja. Terminologia. Wyd. Polski Komitet Normalizacyjny.

Polska Norma PN-86-N-02211 Geodezja. Geodezyjne wyznaczanie przemieszczeń. Terminologia podstawowa. Wyd. Polski Komitet Normalizacyjny.

Potůčková M. 2006. Trends in Geoinformatics Education. Geoinformatics FCE CTU, 1, 35-43.

Prószyński W., Kwaśniak M. 2006. Podstawy geodezyjnego wyznaczania przemieszczeń. Pojęcia i elementy metodyki. Warszawa, Poland.

Puchkov L.A., Petrov V. L. 2017. The system of higher mining education in Russia. Eurasian Mining, 57-60.

Rozporządzenie Ministra Gospodarki Przestrzennej i Budownictwa z dnia 21 lutego 1995 r. w sprawie rodzaju i zakresu opracowań geodezyjno-kartograficznych oraz czynności geodezyjnych obowiązujących w budownictwie (Dz. U. Nr 25, poz. 133).

Rozporządzenie Ministra Środowiska z dnia 20 kwietnia 2007 r. w sprawie warunków technicznych, jakim powinny odpowiadać budowle hydrotechniczne i ich usytuowanie (Dz. U. Nr 86, poz. 579).

Rozporządzenie Ministra Spraw Wewnętrznych i Administracji z dnia 9 listopada 2011 r. w sprawie standardów technicznych wykonywania geodezyjnych pomiarów sytuacyjnych i wysokościowych oraz opracowywania i przekazywania wyników tych pomiarów do państwowego zasobu geodezyjnego i kartograficznego (Dz. U. Nr 263, poz. 1572). 
Rozporządzenie Ministra Rozwoju z dnia 11 września 2020 r. (a) w sprawie szczegółowego zakresu i formy projektu budowlanego (Dz. U. poz. 1609).

Rozporządzenie Ministra Rozwoju z dnia 18 sierpnia 2020 r. (b) w sprawie standardów technicznych wykonywania geodezyjnych pomiarów sytuacyjnych i wysokościowych oraz opracowywania i przekazywania wyników tych pomiarów do państwowego zasobu geodezyjnego i kartograficznego (Dz. U. poz. 1429).

Rybak J., Ivannikov A., Egorova A., Ohotnikova K., Fernandes I. 2017. Some remarks on experience based geotechnical education. International Multidisciplinary Scientific GeoConference Surveying Geology and Mining Ecology Management, SGEM, 17(12), 1003-1012.

Sitanyiova D., Masarovicova S., Drusa M. 2014. Advanced forms of education in Geotechnics from Erasmus intensive Programme to European training networks. International Multidisciplinary Scientific GeoConference Surveying Geology and Mining Ecology Management, SGEM.

Ustawa z dnia 17 maja 1989 r. - Prawo geodezyjne i kartograficzne (t.j. Dz. U. z 2020 r. poz. 2052 z późn. zm.).

Ustawa z dnia 7 lipca 1994 r. - Prawo budowlane (t.j. Dz. U. z 2020 r. poz. 1333 z późn. zm.).

Young G.O., Smith M.J., Murphy R. 2012. Contemporary surveying education changing with the times. Survey Review, 44(326), 223-229.

Dr inż. Zbigniew Muszyński

Wrocław University of Science and Technology

Faculty of Geoengineering, Mining and Geology

ul. Na Grobli 15, 50-421 Wrocław

e-mail: zbigniew.muszynski@pwr.edu.pl

ORCID: 0000-0002-2649-8586

Mgr Paulina Kujawa

Wrocław University of Science and Technology

Faculty of Geoengineering, Mining and Geology

ul. Na Grobli 15, 50-421 Wrocław

e-mail: paulina.kujawa@pwr.edu.pl

ORCID: 0000-0002-7628-6311 